\title{
Modificaciones de las fases y de las resistencias mecánicas del clínker según el tipo de templado desde altas temperaturas
}

\section{Modifications clinker phase and mecanical strength in relation to type of quenching}

F. PUERTAS, Lcda. en Ciencias Químicas, F. TRIVIÑO, Dr. en Ciencias Químicas IETCc/CSIC

\section{RESUMEN}

Ha sido estudiacio el efecto del templado en la estabilidad de las fases de diferentes clinkeres comerciales y los resultados de sus resistencias a flexotracción y compresión a los 7 y 28 dias. El clínker fue recalentado a $1.576^{\circ} \mathrm{C}$ durante treinta minutos y templado al aire y por inmersión en agua. Las muestras se estudiaron por las siguientes técnicas: D.R.X. Microscopia y por análisis dispersivo de rayos $X$.

El clinker templado al agua tiene alita de estructura trigonal con $\mathrm{Mg}$ y Al en disolución sólida. Los clínkeres templados al aire tienen alita monoclínica.

Las resistencias de flexotracción y compresión a 7 y 28 dias de los clinkeres templados al agua fueron siempre más bajas que las de los clinkeres templados al aire. Esto demuestra que la alita trigonal se hidrata más lentamente que la monoclínica.

\section{SUMMARY}

The effect of quenching in the stability of the phases of different commercial clinkers and so its flexotraction and compression strength at 7 and 28 days curing time have been studied. The clinkers were reheated at $1.576^{\circ} \mathrm{C}$, for a period of thirty minutes, and were quenched in two different ways:-outside at air temperature and water submersion. The samples were studied by the techniques: $X R D$, optical microscopy and dispersive $X$-ray analysis. All the water quenched clinker had always a trigonal structured alite, which has $\mathrm{Mg}$ and $\mathrm{Al}$ is solid solution. The air quenched clinkers had a monoclinic alite.

The flexotraction and compression strength at 7 and 28 days of the water quenched clinkers were always lower to those of the air quenched ones. This is due to that the trigonal structured alita hydrates with much more difficulty than the monoclinic alite.

\section{INTRODUCCION}

Las razones fundamentales que justifican un enfriamiento racional del clínker son:

- El clínker recién salido del horno no es transportable.

- El clínker caliente es difícilmente molturable, su fricción con los materiales del molino podría destemplar el acero, y el yeso se deshidrataría explosivamente.

- Un aprovechamiento del contenido térmico del clínker caliente, del orden de $200 \mathrm{kcal} / \mathrm{kg}$ de clinker, que disminuye los costes de producción.

\section{INTRODUCTION}

The main reasons for the rational cooling of clinker are:

- Clinker just out of the kiln is not transportable.

- Hot clinker is difficult to mill. Its friction with mill materials would draw the temper out of the steel and the gypsum would dehydrate explosively.

- To take advantage of the hot clinker's thermal content which is about $200 \mathrm{Kcal} / \mathrm{kg}$ of clinker. This would lower the costs of production. 
- Una mejora en las propiedades del clínker $y$ por lo tanto del cemento.

El clínker abandona la zona de clinkerización en el horno a una temperatura del orden de $1.350^{\circ} \mathrm{C}-1.500^{\circ} \mathrm{C}$; a partir de este momento el enfriamiento progresa más o menos rápidamente según el tipo de enfriador utilizado (1). La temperatura a ia que sale el clínker del enfriador oscila entre $50^{\circ} \mathrm{C}-300^{\circ} \mathrm{C}$

La velocidad de enfriamiento del clínker influye en la relación entre las fases cristalinas y vítreas (2). Si el enfriamiento es muy lento, las fases del clínker continúan su evolución reaccionando entre si hasta aicanzar una cristalización completa. Si el enfriamiento es muy rápido se frena la formación de cristales, y una gran parte de la fase líquida solidifica en estado vítreo.

En las condiciones normales de fabricación el enfriamiento no es, ni lo suficientemente rápido para congelar la fase vítrea, ni lo suficientemente lento para la cristalización total. En el clínker de horno rotatorio la fracción de fases fundidas es del orden de 20-25\%. Un enfriamiento relativamente rápido desde la temperatura de clinkerización es necesario si se quiere evitar la tendencia del silicato tricálcico a descomponerse (3). K. Mohan and F. P. Glasser (4) dicen que la descomposición del $\mathrm{C}_{3} \mathrm{~S}$, con un enfriamiento lento, se inicia a temperaturas comprendidas entre $1.210^{\circ} \mathrm{C}-1.025^{\circ} \mathrm{C}$.

Las fases del clínker del cemento Portland se ven afectadas según el tipo de enfriamiento experimentado:

\section{Alita}

Con un enfriamiento lento el $\mathrm{C}_{3} \mathrm{~S}$ se descompone por encima de $1.025^{\circ} \mathrm{C}$, según la reacción:

$$
\mathrm{C}_{3} \mathrm{~S} \rightarrow \mathrm{C}_{2} \mathrm{~S}+\mathrm{C}
$$

A esta cal se la denomina cal secundaria. Los cristales grandes de alita tardan en hidratarse, disminuyendo las resistencias mecánicas iniciales y finales.

\section{Belita}

Los cristales grandes de belita si no tienen la cantidad suficiente de estabilizadores y su tamaño es superior a $10 \mu \mathrm{m}$, tienden a favorecer la transformación polimórfica con lo que el clínker se desintegraría y disminuirian notablemente ias resistencias mecánicas.
- An improvement in ciinker properties and thereby a quality improvement in the cement.

Clinker leaves the clinkerization zone of the kiln at a temperature of about $1.350^{\circ} \mathrm{C}-1.500^{\circ} \mathrm{C}$. As of this moment the cooling progress more or less rapidly on which type of cooler is used (1). The clinker leaves the cooler at a temperature that fluctuates between $50^{\circ} \mathrm{C}-300^{\circ} \mathrm{C}$.

The clinker cooling rate influences the relationship between the crystalline and vitreous phases (2). If the cooling is slow the clinker's phases continue their evolution reacting among themselves until they reach the point of complete crystallization. If the cooling is very fast crystal formation is slowed down and a large part of the liquid phase solidifi into a vitreous state.

Under normal production conditions the cooling is neither too fast to freeze the vitreous phase nor too slow for total crystallization. In rotary-kiln clinker the percentage or liquid phase is about $20-25 \%$. A relatively fast cooling down from clinkerization temperatures is necessary if one wants to avoid the tendency of tricalcic silicate to decompose (3). K. Mohan and F. P. Glasser (4) say that decomposition of $\mathrm{C}_{3} \mathrm{~S}$ begins at temperatures between $1.210^{\circ} \mathrm{C}-1.025^{\circ} \mathrm{C}$ with slow cooling.

Portland cement clinker phases are seen to be affected according to the type of cooling method used:

\section{Alite}

With slow cooling $\mathrm{C}_{3} \mathrm{~S}$ decomposes above $1.025^{\circ} \mathrm{C}$ in accordance with the reaction:

$$
\mathrm{C}_{3} \mathrm{~S} \rightarrow \mathrm{C}_{2} \mathrm{~S}+\mathrm{C}
$$

This lime is called secondary lime. The large alite crystals are slow to hydrate thereby diminishing the initial and final mechanical strength.

\section{Belite}

If the large belite crystals do not have enough stabilizers and their size is greater than $10 \mu \mathrm{m}$ they tend to favour polimorphic transformation $\beta \rightarrow \gamma$ with which the clinker would desintegrate and the mechanical strength diminish considerably. 


\section{Aluminato tricálcico}

Los cristales grandes de $\mathrm{C}_{3} \mathrm{~A}$ tienen una menor velocidad de hidratación en presencia de yeso, retrasándose el principio y el final del fraguado. En un enfriamiento rápido el $\mathrm{C}_{3} \mathrm{~A}$ permanece en estado vítreo, y es poco sensible al ataque por soluciones de sulfato de sódio y de magnesio.

\section{Fase ferrítica}

Los cristales grandes de $\mathrm{C}_{4} \mathrm{AF}$ son menos reactivos frente al agua y al yeso.

\section{Periclasa}

La hidratación de grandes cristales de periclasa se acompaña de un aumento de volumen, discurre más lentamente que en las otras fases del clínker y esto altera la estabilidad del volumen del cemento durante el período de endurecimiento. El enfriamiento rápido del clínker permite un mayor contenido de $\mathrm{MgO}$.

En el presente trabajo, se estudia la influencia de diferentes tipos de templado (al aire y por inmersión en agua) en varios clínkeres, respecto a la formación de sus fases y a las resistencias mecánicas a flexotracción y compresión.

\section{TRABAJO EXPERIMENTAL}

Se utilizaron dos clínkeres de cemento Portland: 1 y 3, cuyas composiciones en \% en peso están en la tabla I. También se preparó un clínker de laboratorio de igual composición química que el n. ${ }^{\circ} 1$, al que se denominó n. ${ }^{\circ} 2$.

\section{Tricalcium Aluminate}

The large $C_{3} A$ crystals have a slower hydration rate in the presence of gypsum thereby slowing down the beginning and final stages of the setting. In a fast cooling the $C_{3} A$ remains in a vitreous state and isn't very susceptible to magnesium and sodium sulphate solution attacks.

\section{Ferritic Phase}

The large $C_{4} A F$ crystals are less reactive in the presence of water and gypsum.

\section{Periclase}

The hydration of large periclase crystals is accompanied by an increase in volume. It flows more slowly than in the other clinker phases and this alters the volume stability of the cement during its hardening period. Rapid cooling of the clinker permits a large $\mathrm{MgO}$ content.

In the present work we have studied the influence of different types of quenching (air and water) on various clinkers with respect to its phase formations and mechanical strength: flexotraction and compression.

\section{EXPERIMENTAL WORK}

Two Portland cement clinkers were used, 1 and 3. Their compositions in percentages by weight are in Table 1. A laboratory clinker was also prepared with the same chemical composition as n. 1 which has been called n. ${ }^{\circ} 2$.

\begin{tabular}{|c|c|c|c|c|c|c|c|c|c|}
\hline Clinkeres & $\mathbf{S i O}_{\mathbf{2}}$ & $\mathbf{A l}_{\mathbf{2}} \mathbf{O}_{\mathbf{3}}$ & $\mathbf{F e}_{\mathbf{2}} \mathbf{O}_{\mathbf{3}}$ & $\mathbf{C a O}$ & $\mathbf{M g O}$ & $\mathbf{S O}_{\mathbf{3}}$ & $\mathbf{N a}_{\mathbf{2}} \mathbf{O}$ & $\mathbf{K}_{\mathbf{2}} \mathbf{O}$ & CaO libre \\
\hline 1 & 22,07 & 5,04 & 2,93 & 66,34 & 2,20 & 0,50 & 0,23 & 0,53 & 0,38 \\
2 & 22,07 & 5,04 & 2,93 & 66,72 & 2,20 & 0,50 & - & 0,50 & - \\
3 & 20,44 & 6,14 & 3,89 & 66,87 & 1,42 & 1,30 & - & - & 0,76 \\
\hline
\end{tabular}

La composición potencial de estos clínkeres a partir de los cálculos de Bogue es:
From Bogue's calculations the potencial compositions of these clinkers is as follows: 
TABLA II

\begin{tabular}{|c|r|r|c|}
\hline & \multicolumn{1}{c|}{$\mathbf{1}$} & $\mathbf{2}$ & $\mathbf{3}$ \\
\hline $\mathrm{C}_{3} \mathrm{~S}$ & $61,24 \%$ & $64,33 \%$ & $63,19 \%$ \\
$\mathrm{C}_{2} \mathrm{~S}$ & $17,16 \%$ & $14,83 \%$ & $11,01 \%$ \\
$\mathrm{C}_{3} \mathrm{~A}$ & $8,4 \%$ & $8,4 \%$ & $9,69 \%$ \\
$\mathrm{C}_{4} \mathrm{AF}$ & $8,9 \%$ & $8,9 \%$ & $11,82 \%$ \\
\hline
\end{tabular}

El clínker n.o 1 se calentó en un horno eléctrico a las temperaturas: $1.100^{\circ} \mathrm{C}, 1.206^{\circ} \mathrm{C}$, $1.320^{\circ} \mathrm{C}, 1.460^{\circ} \mathrm{C}$ y $1.576^{\circ} \mathrm{C}$, durante treinta minutos. Para cada temperatura, las muestras fueron templadas de dos formas diferentes:

A) $\mathrm{Al}$ aire hasta temperatura ambiente C.T.A.

B) Sumergiéndolos en el agua hasta temperatura ambiente C.T.H.

Los clínkeres 2 y 3 se calentaron sólo a $1.576^{\circ} \mathrm{C}$ y los templados fueron realizados de las dos formas descritas anteriormente.

Las muestras recocidas de los clinkeres 1, 2 y 3 , con dos distintos templados, para cada temperatura, fueron analizadas por difracción de rayos $X$, microscopía óptica y análisis dispersivo de rayos $X$.

El difractómetro utilizado fue un Philips PW 1700. Se empleó un Kevex System 7000 para el análisis dispersivo de rayos $X$.

En algunas muestras se hicieron tratamientos de disolución de silicatos con la mezcla de metanol-salicílico, para detectar los compuestos de la fase vítrea del clínker que permanecen insolubles (5 y 6 ).

Se prepararon probetas prismáticas de $1 \times 1 \times 6 \mathrm{~cm}$, con una relación arena/cemento de $3: 1$ con arena monogranular y una relación agua/cemento de 0,66 , para todas las muestras tratadas de los clínkeres n. ${ }^{\circ} 1,2$ y 3 .

\section{RESULTADOS}

\subsection{Difracción de rayos $X$}

\subsubsection{Muestras anhidras}

Los difractogramas de todos los clínkeres templados al aire C.T.A. (figura n. ${ }^{\circ} 1$ ) tienen características similares: su alita cristaliza en
Clinker $n .^{\circ} 1$ was heated in an electric kiln at the following temperatures: $1.100^{\circ} \mathrm{C}, 1.206^{\circ} \mathrm{C}$, $1.320^{\circ} \mathrm{C}, 1.460^{\circ} \mathrm{C}$, and $1.576^{\circ} \mathrm{C}$, for a period of thirty minutes. For each temperature the clinkers were quenched in two different ways. A. Outside at air temperature of A.Q.S. (air
quenching clinker).

B. Water submersion at ambient temperature or W.Q.C. (water quenching clinker).

Clinkers n. 2 and n. 3 were only heated at $1.576^{\circ} \mathrm{C}$ and the two proviously. described quenching methods were employed.

A Philips P. W. 1.700 difractometer and a Kevex System 7.000 for the dispersive $X$-Ray analysis were used.

Some samples were treated with salicylicmethanol solution in order to disolve the silicate phases and detect the composition of the clinker's vitreous phase which remains insoluble (5 and 6).

It was prepared a prismatic mortar samples of $1 \times 1 \times 6 \mathrm{~cm}$ with a sand/cement ratio of 3: 1 and a water/cement ratio of 0.66 for all the treated samples of clinker $n .^{\circ} 1, n .^{\circ} 2$ and n. ${ }^{\circ} 3$.

\section{RESULTS}

\subsection{X-Ray Diffraction}

\subsubsection{Anhydrous samples}

The X-Ray diffraction patterns of all the A.Q.C. (figure n. ${ }^{\circ}$ 1) had similar characteristics: its alite crystallizes in the monoclinic system, 
el sistema monoclínico, posiblemente del tipo $M_{3}+M_{1}$, identificado por el pico de $51,70^{\circ}$.

Su fase ferrítica tiene una composición comprendida entre $\mathrm{C}_{4} \mathrm{AF}$ y $\mathrm{C}_{6} \mathrm{~A}_{2} \mathrm{~F}$, es decir una fase ferrítica con alto contenido en alúmina. En estos clínkeres templados al aire (C.T.A.) se observa poco contenido en aluminato tricálcico.

Los difractogramas de los clínkeres templados al agua (C.T.H.) (figura n.॰2), tienen las siguientes caracteristicas comunes: su alita cristaliza en el sistema trigonal y tienen poca fase ferrítica cristalizada, la que lo está, es muy pobre en alúmina con una composición

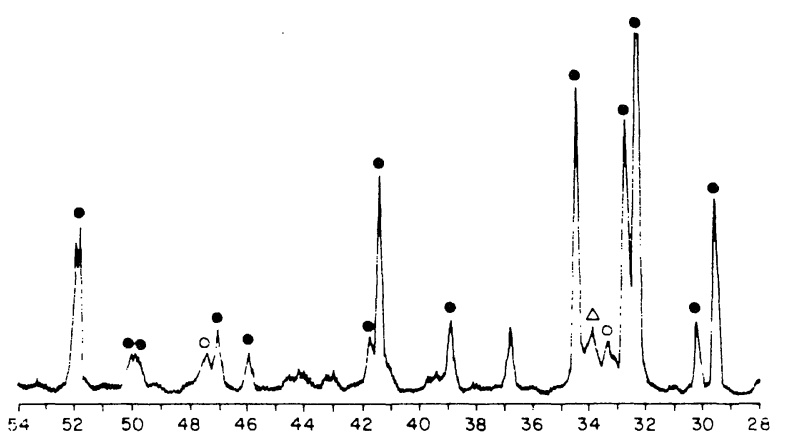

$$
\begin{array}{ll}
\text { Clinker } n \circ 1 & \text { Clinker } n \circ 1 \\
\text { templadc al aire } & \text { air quenched } \\
\text { desde } 1.576 \circ \mathrm{C} & \text { from } 1.576 \% \mathrm{C}
\end{array}
$$
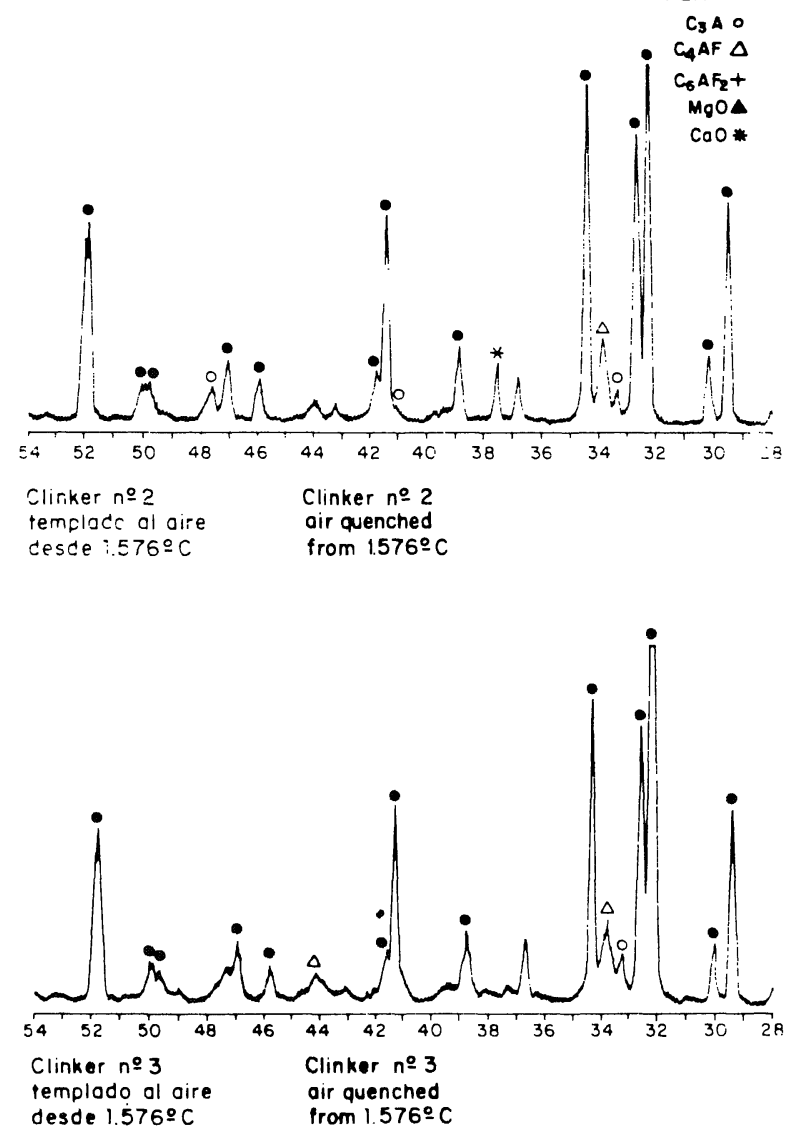

Fig. 1 possibly the $M_{3}+M_{1}$ type, identified by a peak of $51.70^{\circ}$. Its ferritic phase has a composition between $C_{4} A F$ and $C_{6} A_{2} F$. This means a ferritic phase with a high alumina content. In those A.Q.C. very little tricalcium aluminate is seen.

The X-Ray diffraction patterns of the W.Q.C. (figure 2) have the following characteristics in common: Their alites crystallize in the trigonal system and they have very little crystallized ferritic phase. This being so it is very poor in aluminate with a composition close to $C_{6} A F_{2}$.
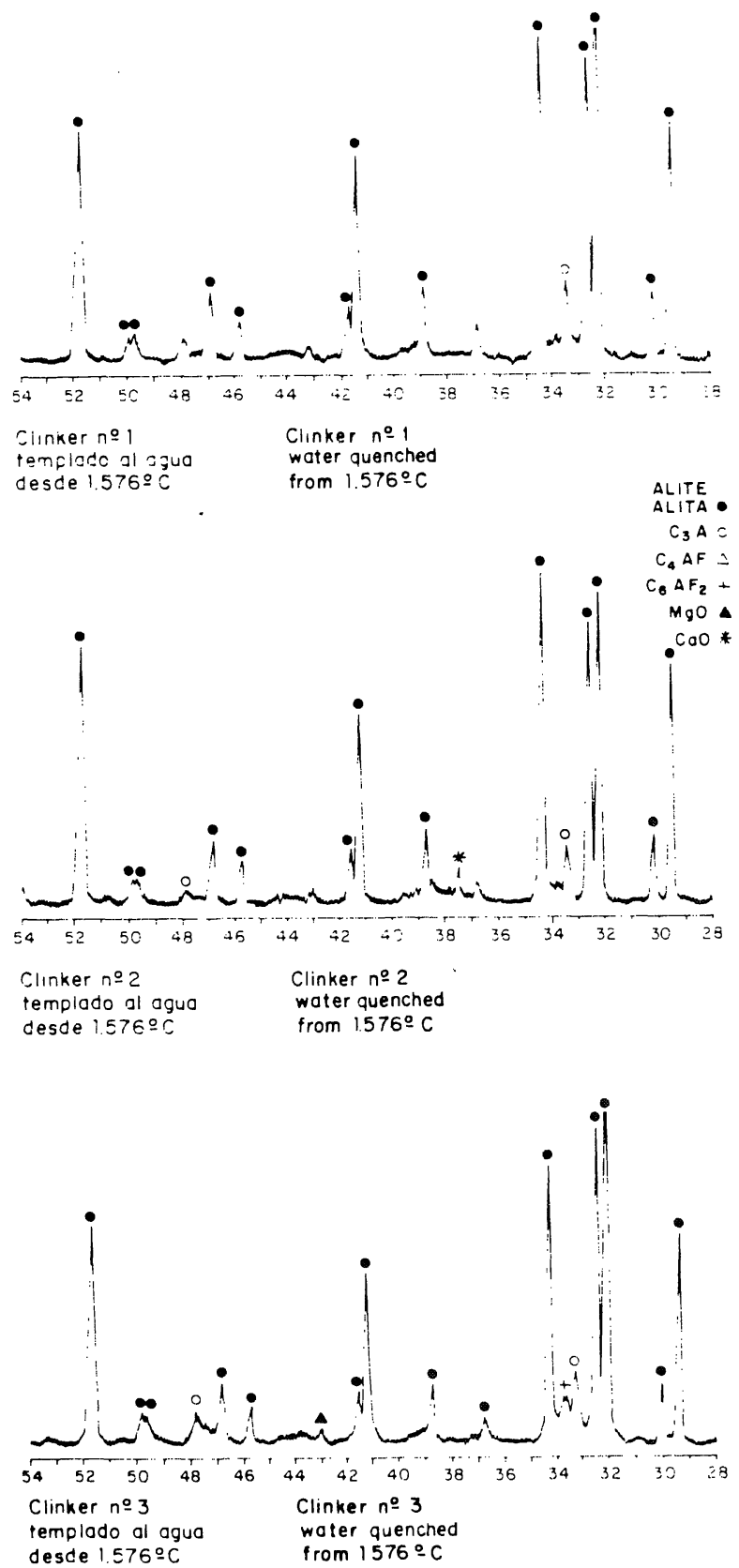

Fig. 2 
próxima a $\mathrm{C}_{6} \mathrm{AF}$; por el contrario tiene una gran cantidad de aluminato tricálcico, posiblemente con hierro en disolución, que distorsiona la red.

En la figura n. 3 aparecen los difractogramas de las muestras tratadas con metanol-salicílico, del clínker n. ${ }^{\circ} 1$ tratado a $1.576^{\circ} \mathrm{C}$ y templado al aire y al agua.
On the other hand it has a large tricalcium alumnate content, possibly with iron in solution, which distorts the lattice.

In the figure n.o 3 are the X.R.D. patterns of the samples were treated by salicylic-methanol solution of clinker n. 1 heated at $1.576^{\circ} \mathrm{C}$ and quenched by the two methods described (air and water).
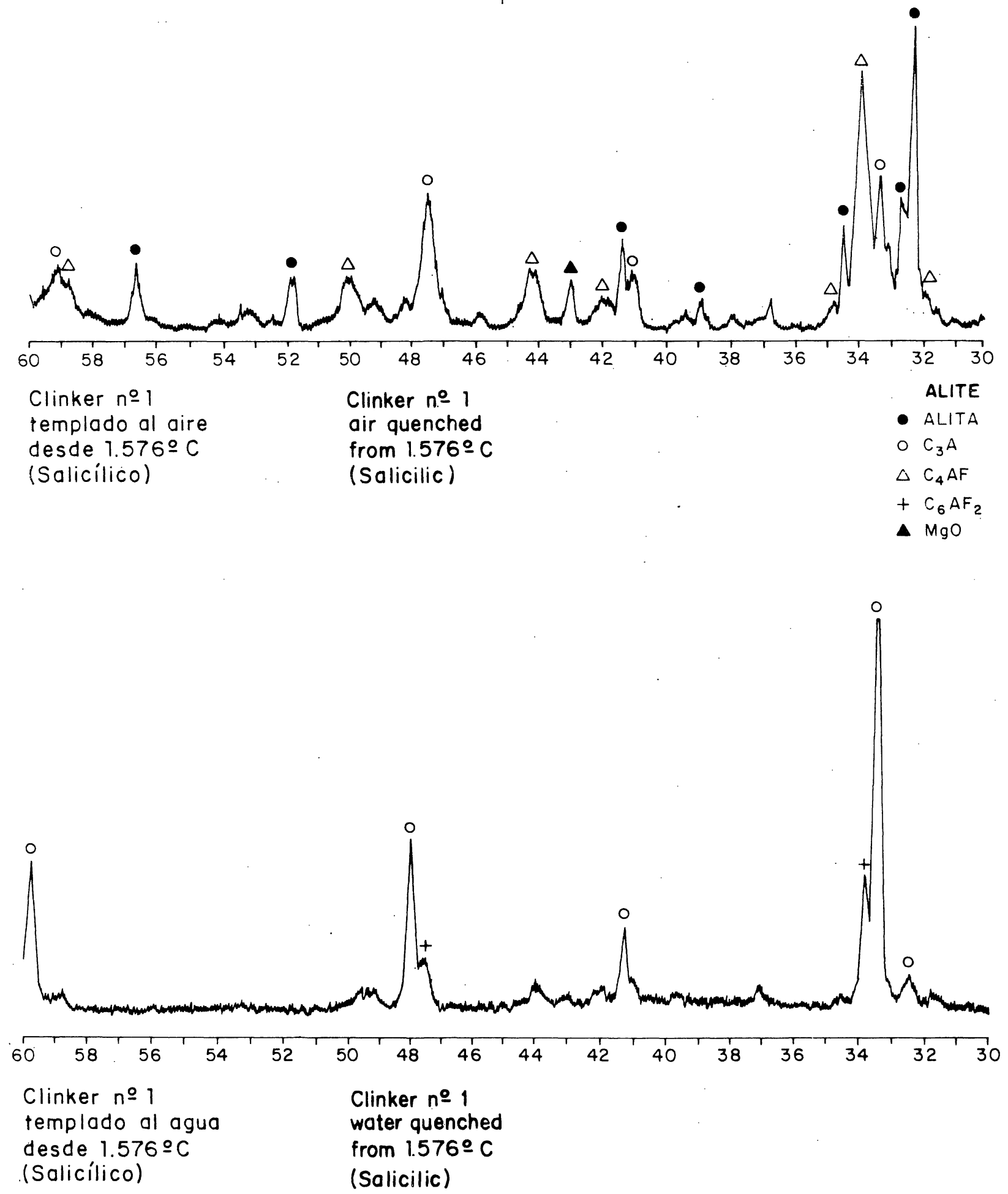

Fig. 3 


\subsubsection{Muestras hidratadas}

Los productos de hidratación de los clínkeres 1,2 y 3 templados al aire y al agua desde $1.576^{\circ} \mathrm{C}$, a los 18 días de curado, fueron estudiados por DRX.

En la figura 4 aparecen los difractogramas de las pastas hidratadas del clínker n. ${ }^{\circ} 1$ templado al aire y al agua desde $1.576^{\circ} \mathrm{C}$. En el difractograma del producto hidratado del clínker 1 templado al aire no se detecta alita; sin embargo, en los restantes productos de hidratación de los otros clínkeres con distintos templados, se observa siempre cierta cantidad de alita. Esta cantidad es considerablemente mayor en los clínkeres templados al agua. En la pasta hidratada de todos los clínkeres templados al agua hay siempre aluminato tricálcico, que no se detecta en los templados al aire.

\subsubsection{Hydrated samples}

The X.R.D. patterns of the hydrated paste of A.Q.C. and W.Q.C. n. 1 , appear in figure 4. In the X.R.D. patterns of the A.Q.C. n.o 1 hydrated product the alite cannot be detected. However, in the rest of the hydrated products of the other clinkers that have been quenched by different method, a certain amount o alite is always detected. This amount is considerably higher in the W.Q.C. In the hydrated paste of all the W.Q.C. there is always tricalcium aluminate which is not detected in those quenched by air.
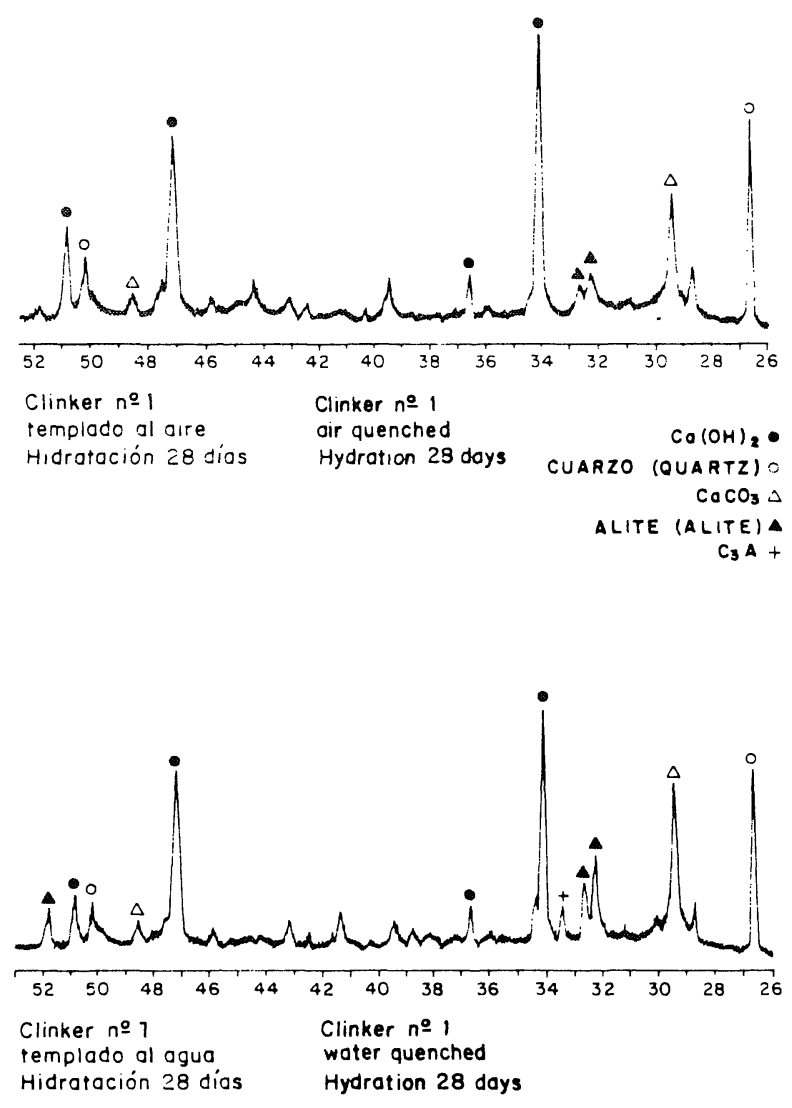

Fig. 4

\subsection{Microscopía óptica}

El cínker n. 1 tratado a $1.100^{\circ} \mathrm{C}$ y $1.576^{\circ} \mathrm{C}$ y templado al aire (CTA) y al agua (C.T.H.) y los clínkeres n. 2 y 3 tratados a $1.576^{\circ} \mathrm{C}$ y templados de las dos formas descritas, fueron estudiados en un microscopio petrográfico.

\subsection{Optic Microscopy}

Clinker n. 1 treated at $1.100^{\circ} \mathrm{C}$ and $1.576^{\circ} \mathrm{C}$, A.Q.C. and W.Q.C. $n .^{\circ} 2$ and n. 3 treated at $1.576^{\circ}$ C, also A.Q.C. and W.Q.C. were studied under a petrographic microscope. The samples, pressed in resin, were polished and treated 
Las muestras embutidas en resina fueron pulidas y atacadas con Nital para diferenciar las fases.

La figura 5.1 corresponde al clínker n. 1 sin recocido. El mismo calentado a $1.576^{\circ} \mathrm{C}$ y templado al aire (C.T.H.) (figura 5.2) y al agua C.T.H. (figura 5.3). Se observa que los cristales de alita y belita son mayores en el clínker templado al agua (C.T.H.) que en el clínker templado al aire C.T.A. y en el clínker sin recocido. Así mismo, en el clínker n.० 1 templado al agua parece haber menos cantidad de fase intesticial que en el templado al aire.

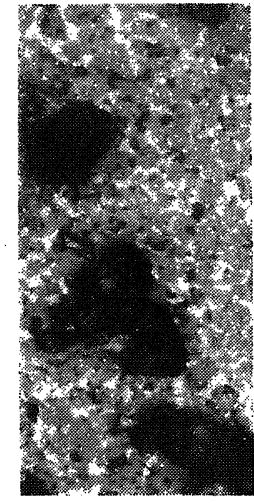

Sin recalentamiento.

Without reheating. Fig. 5.1

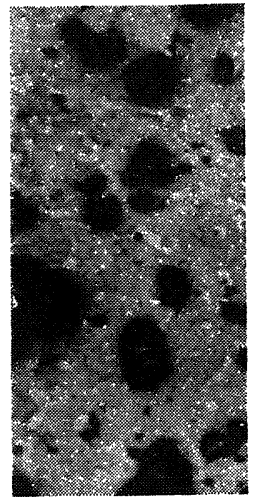

Clínker n.० 1

Templado al agua. Templado al aire. Water quenched. Fig. 5.2.

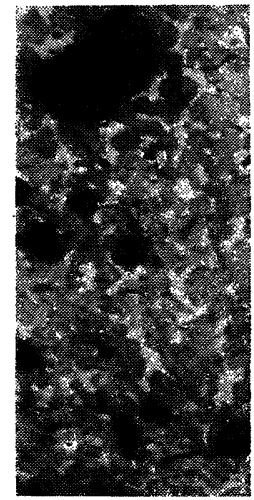

Aire quenched, Fig. 5.3.
La figura 6.1. corresponde al clínker n. 1 calentado a $1.100^{\circ} \mathrm{C}$ y templado al aire C.T.R. y al agua C.T.H. respectivamente en la figura 6.2. Se observa que el borde de los granos de alita es más nítido y recto en el templado al agua que en el templado al aire.

\subsection{Análisis dispersivo de rayos $X$}

a) El clínker n.० 1 templado al aire C.T.A. desde $1.576^{\circ} \mathrm{C}$.

- En la fase intersticial los elementos presentes son: $\mathrm{Ca}, \mathrm{Si}, \mathrm{Al}, \mathrm{Ti}$ y $\mathrm{Fe}$.

- En los cristales de alita los elementos detectados son: $\mathrm{Ca}, \mathrm{Si}$ y $\mathrm{Mg}$.

- En los cristales de belita aparecen: $\mathrm{Si}, \mathrm{Ca}$, $\mathrm{K}$, Ti y $\mathrm{Fe}$.

b) Clínker n.o 1 templado al agua C.T.H. desde $1.576^{\circ} \mathrm{C}$ with Nital to differentiate the phases.

The figure n. ${ }^{\circ}$ 5.1. corresponds to clinker $n .{ }^{\circ} 1$ without reheating. The same A.Q.C. heate at $1.576^{\circ} \mathrm{C}$ is presented in figure 5.2.; figure 5.3 shows the same W.Q.C. It is seen that the alite and belite crystals are larger in the W.Q.C. than in the A.Q.C. and the clinker without reheating. Likewise W.Q.C. n.o 1 seems to have less insterstitial phase quantity than the A.Q.C. one.
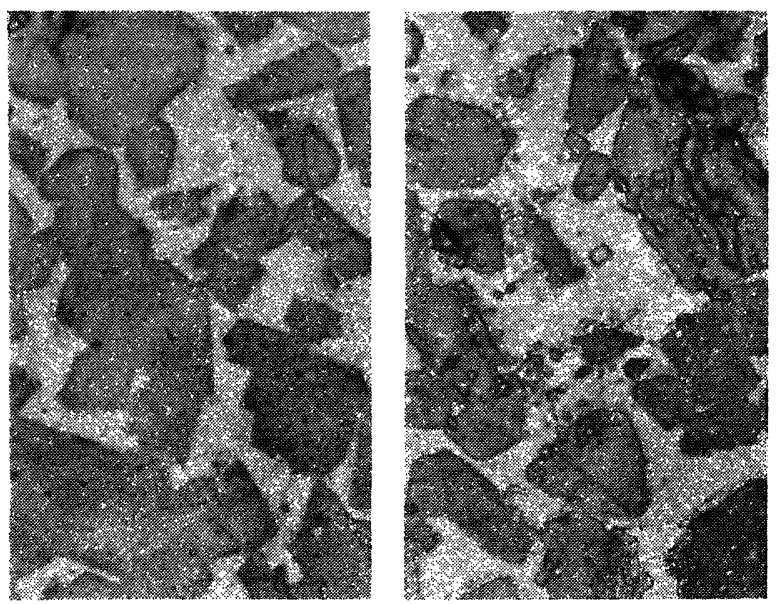

$$
\begin{array}{cc} 
& \multicolumn{2}{c}{\text { Clínker n. } 1} \\
\text { Templado al agua. } & \text { Templado al aire. } \\
\text { Water quenched. } & \text { Air quenched. } \\
\text { Fig. 6.1. } & \text { Fig. 6.2. }
\end{array}
$$

In the figure 6.1 correspond to A.Q.C. n. ${ }^{\circ}$ heated at $1.100^{\circ} \mathrm{C}$, and figure 6.2 and W.Q.C. It is seen that the edges of the alite grains are clearer and straighter in the W.Q.C. ones that in the A.Q.C. ones.

\subsection{Dispersive X-Ray Analysis}

a) A.Q.C. n. 1 from $1.576^{\circ} \mathrm{C}$.

- The elements present in the interstitial phase are: $\mathrm{Ca}, \mathrm{Si}, \mathrm{Al}, \mathrm{Ti}$ and $\mathrm{Fe}$.

- The elements detected in the alite crystals are: $\mathrm{Ca}, \mathrm{Si}$ and $\mathrm{Mg}$.

- In the belite crystals appear. Ca, Si, K, Ti and $\mathrm{Fe}$.

b) W.Q.C. n. 1 from $1.576^{\circ} \mathrm{C}$. 
- En la fase intersticial están presentes los elementos: $\mathrm{Ca}, \mathrm{Si}, \mathrm{Al}, \mathrm{Ti}, \mathrm{Fe}, \mathrm{Mg}$ y $\mathrm{K}$.

- En los cristales de alita los elementos encontrados son: $\mathrm{Ca}, \mathrm{Si}, \mathrm{Al}, \mathrm{Fe}, \mathrm{Mg}, \mathrm{K}$, $\mathrm{Cr}, \mathrm{S}, \mathrm{Ti}$.

- En los cristales de belita los elementos detectados son: $\mathrm{Ca}$, Si y K.

\subsection{Resistencias mecánicas}

Para el clínker n. 1 , a los 7 dias de curado, las mayores resistencias a flexotracción y compresión se obtienen para el clínker sin recocido seguido del clínker templado al aire, como se puede apreciar en las figuras 7 y 8 . Las resistencias mecánicas del clínker templado al agua se mantienen prácticamente constantes a todas las temperaturas de templado.

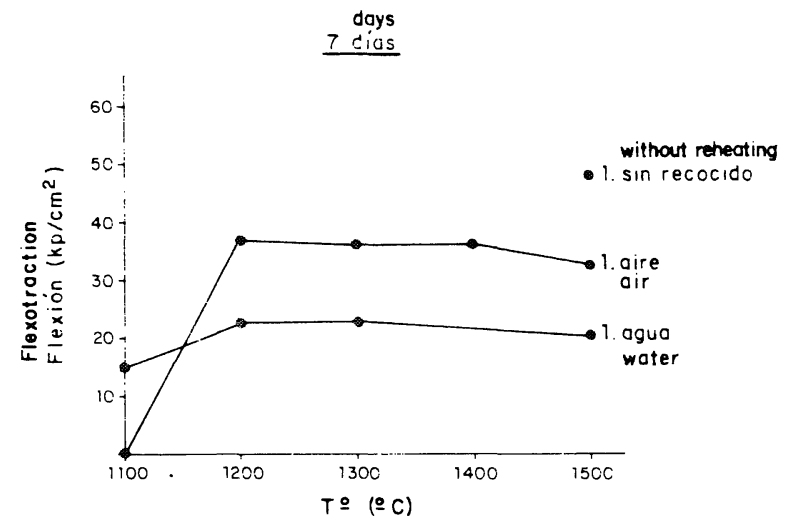

Fig. 7

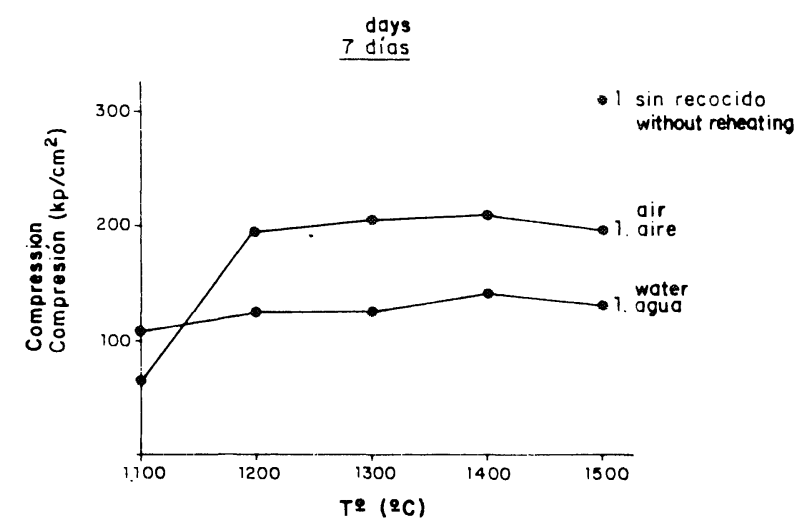

Fig. 8
- The elements present in the interstitial phase are: $\mathrm{Ca}, \mathrm{Si}, \mathrm{Al}, \mathrm{Ti}$ and $\mathrm{Fe}, \mathrm{Mg}, \mathrm{K}$.

- The elements detected in the alite cristals are: $\mathrm{Ca}, \mathrm{Si}, \mathrm{Al}$ and $\mathrm{Mg}, \mathrm{Fe}, \mathrm{K}, \mathrm{Cr}, \mathrm{S}, \mathrm{Ti}$.

- The elements detected in the belite cristals are: $\mathrm{Ca}$, Si and $\mathrm{K}$.

\subsection{Mechanical strength}

For clinker $n .^{\circ} 1$ with a 7 day curing period the greatest flexotraction and compression resistances were obtained by the clinker without reheating followed by the A.Q.C. as can be seen in figures 7 and 8 . The mechanical resistances of the W.Q.C. n.o 1 remained practically constant for all temperatures.

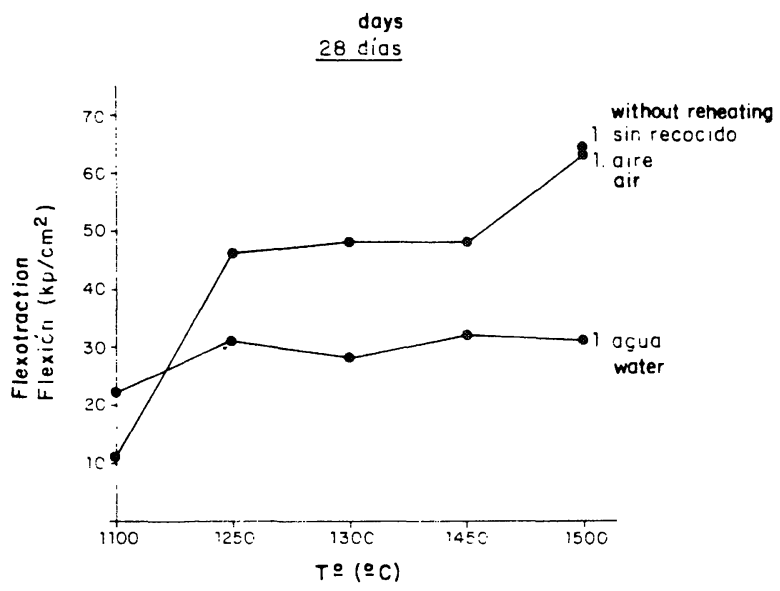

Fig. 9

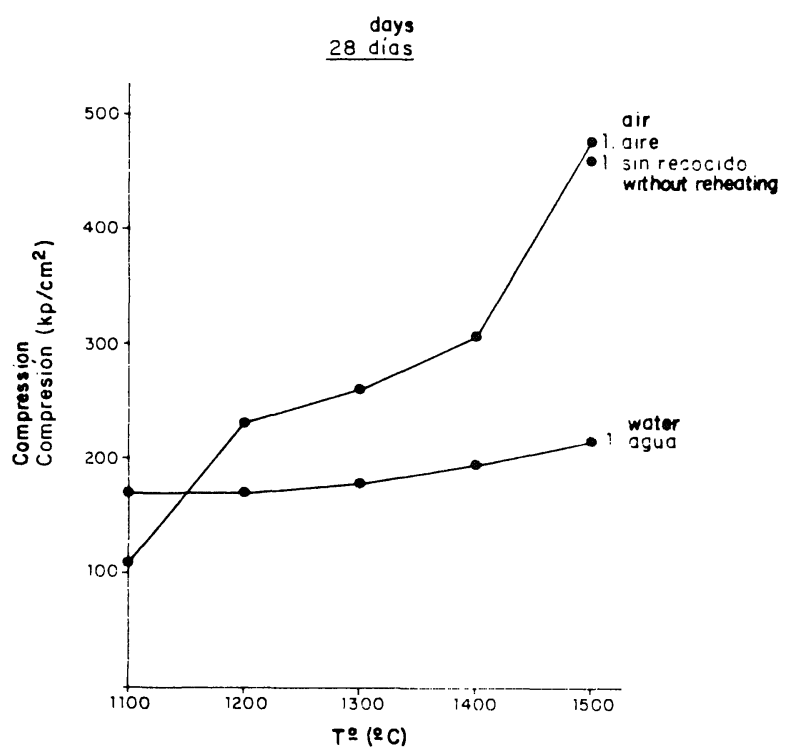

Fig. 10 
A los 28 dias de curado (figuras 9 y 10), hay poca diferencia en las resistencias mecánicas entre el clínker sin recocido y el templado al aire desde $1.576^{\circ} \mathrm{C}$. El clínker templado al agua da resistencias de mismo orden o inferiores a los de los otros dos a todas las temperaturas estudiadas, excepto a $1.100^{\circ} \mathrm{C}$.

En la figura 11 se representan las resistencias mecánicas a rotura a flexotracción y compresión a los 7 y 28 días de curado en agua desionizada para los clínkeres n.० 1,2 y 3 tratados a $1.576^{\circ} \mathrm{C}$ y templados al aire y al agua. En todos los casos se aprecia que los clínkeres templados al aire dan mayores resistencias que los templados al agua.
For the 28 day cured ones (figures 9 and 10) there is little difference in the mechanical strength between the clinker without reheating and the A.Q.C. one from $1.576^{\circ}$ C. The W.Q.C. had strenght of the same order or inferior to those of the other two at all temperatures studied except at $1.100^{\circ} \mathrm{C}$.

Figure 11 represents the mechanical strength by flexotraction and compression breakage of clinkers n. 2 and n.० 3, A.Q.C. treated at $1.576^{\circ} \mathrm{C}$, and cured in deionized water for a period of 7 and 28 days. In all cases it is appreciated that the A.Q.C. have greater strengt than the W.Q.C. ones.

- 1.A.Q.C
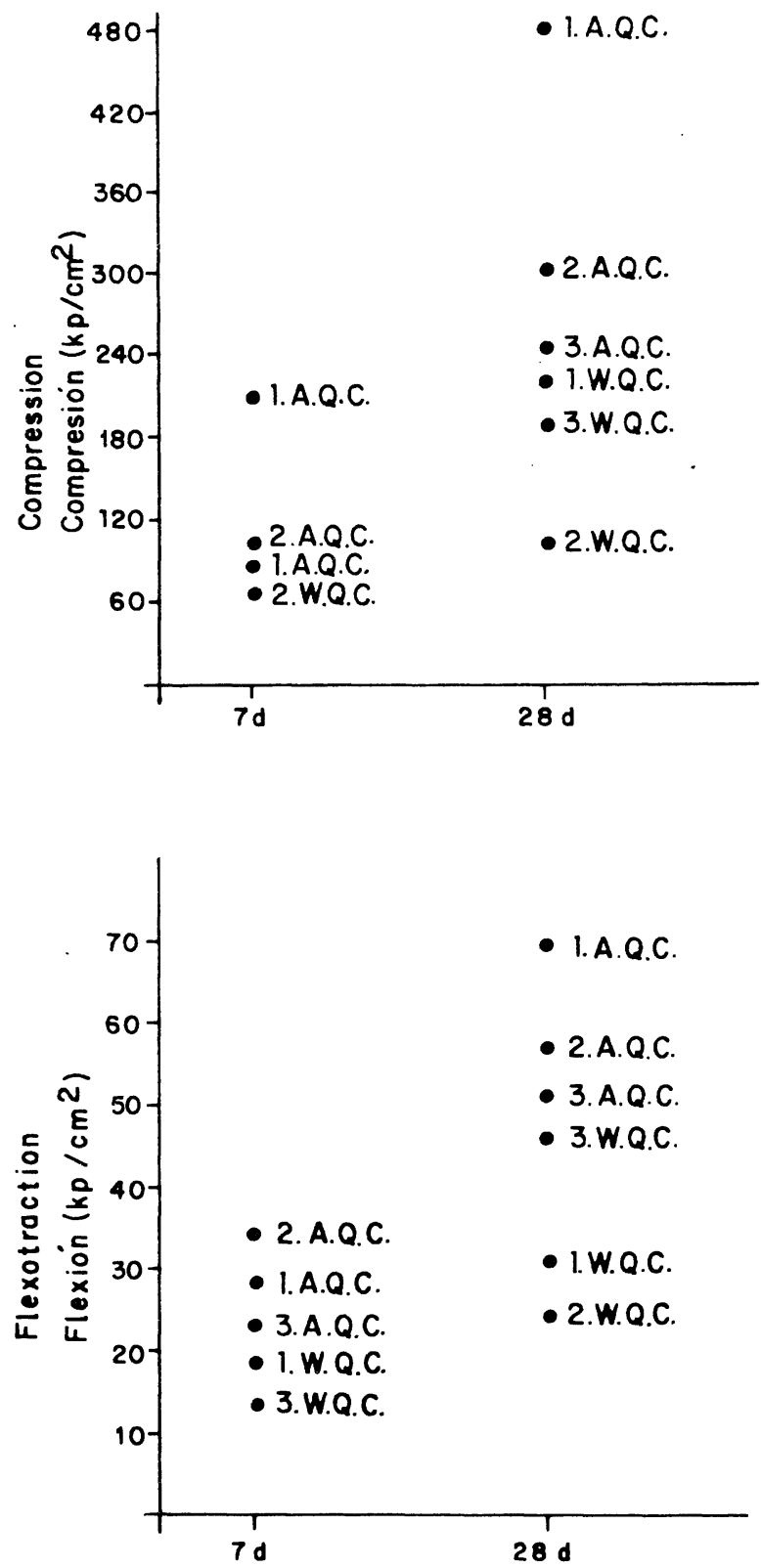

Fig. 11 


\section{Granulometria}

En la figura 12, representa el \% de material retenido frente a la luz de malla de los tamices para el clínker n. 1 templado al aire y al agua desde $1.576^{\circ} \mathrm{C}$ y del clínker sin recocido.

En la figura 13 se representa la granulometría del clínker antes de la molienda, apreciándose que el tamaño de los granos del clínker sin recocido es superior al de los templados al aire y al agua. Después de la molienda se observa que los granos más finos corresponden al clínker sin recocido, siendo los de mayor tamaño los del templado al agua.

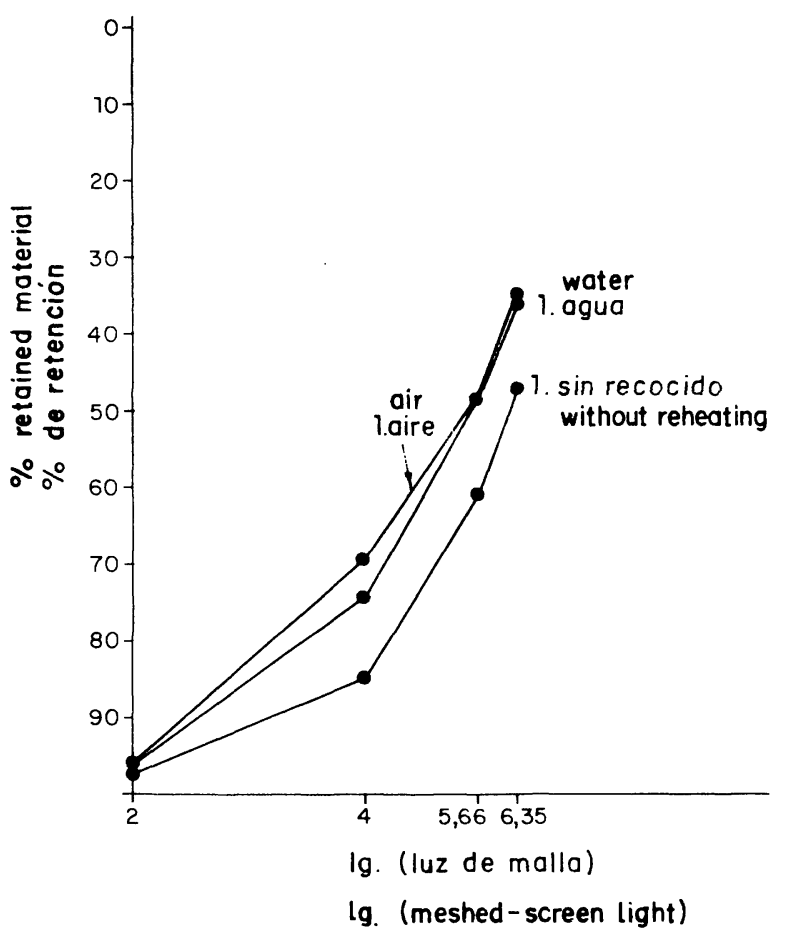

Fig. 12

\subsection{Coloración del clínker}

Hay una marcada diferencia que se observa a simple vista, según el tipo de templado efectuado: el distinto color de los clínkeres. El clínker templado al agua desde altas temperaturas $\left(1.576^{\circ} \mathrm{C}\right)$ es de color amarillo no sólo en su parte externa sino también en la interna. Este color amarillo se va perdiendo según disminuye la temperatura de tratamiento. A los $1.460^{\circ} \mathrm{C}$ permanece el color amarillo aunque más oscurecido. $\mathrm{A} 1.320^{\circ} \mathrm{C}$ los gránulos de clínker son de color grisáceo normal.

\subsection{Granulometry}

Figure 12 represents the percentage of retained material before a meshed-screen light of clinker n. 1 A.Q.C. and W.Q.C. from $1.576^{\circ} \mathrm{C}$, and clinker without reheating.

Figure 13 represents the granulometry of the clinker before milling. We can appreciate that the grain sizes of the clinker without reheating are superior to the A.Q.C. and W.Q.C. ones. After milling it is been that the finest grains belong to the clinker without reheating, the largest size belonging to the W.Q.C.

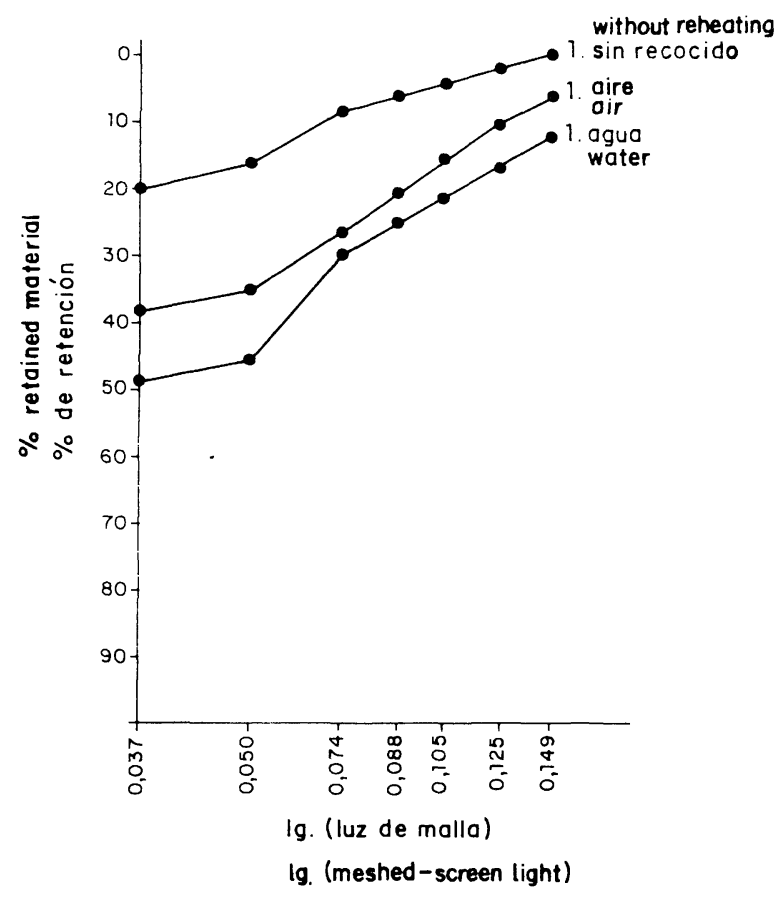

Fig. 13

\subsection{Clínker colouration}

There is a marked difference in the clinkers colouring depending on the type quenching used and these can be seen with the naked eye. W.Q.C. from high temperatures $\left(1.576^{\circ} \mathrm{C}\right)$ is yellow, not only externally but also internally as well. This yellow colour is lost as the treatment diminishes. At $1.460^{\circ} \mathrm{C}$ the yellow is still there although it is darker. At $1.320^{\circ} \mathrm{C}$ the clinker granules are normal greycolour. 


\section{DISCUSION}

Los resultados experimentales obtenidos por nosotros parecen no concordar con los datos bibliográficos respecto a la influencia de los templados en la cristalización de las fases del clínker y de sus resistencias mecánicas.

Hay que tener en cuenta, que en nuestro caso las temperaturas de tratamiento son muy elevadas $\left(1.575^{\circ} \mathrm{C}\right)$, y los templados al aire y al agua, son mucho más bruscos que los que sufre un clínker comercial.

A partir de microscopía se ha establecido que la alita del clínker del cemento Portland aparece en las formas: $M_{1}$ y $M_{2}$ (7) (8) (9). Por difracción de rayos $X$, las dos formas identificadas son la $R$ (trigonal) y la $M_{1}$ (del tipo $M_{1 b}$ ) (10). La forma $M_{1 b}$ tiene un difractograma de rayos $\mathrm{X}$ muy similar a la $\mathrm{M}_{3}(11)$.

Nosotros hemos identificado, por el espectro de difracción de rayos $X$, en los clínkeres templados al agua, una alita de estructura trigonal, que es la forma polimórfica de mayor temperatura, y para los clínkeres templados al aire una alita de tipo monoclínico, posiblemente una mezcla de las formas $M_{1}$ y $M_{3}$.

Una posible justificación a las bajas resistencias mecánicas obtenidas para los clínkeres templados al agua, podría ser la estabilización de esta alita trigonal que tiene sustituciones de $\mathrm{Ca}$ y $\mathrm{Si}$ (observadas por análisis dispersivo de rayos $\mathrm{X}$ ) por $\mathrm{Mg}$ y $\mathrm{Al}$ respectivamente. Estas sustituciones dan lugar a la formación de cristales de relativo gran tamaño y con perfiles muy marcados y rectos, que tienen por tanto una menor reactividad frente al agua, y que justifican de esta manera las bajas resistencias a flexotracción y compresión de los clínkeres templados al agua. Por otra parte es sabido que la disminución de la distancia del enlace $\mathrm{Ca}-\mathrm{O}$ por sustitución metálica disminuye la reactividad.

Los clínkeres templados al aire, tienen una alita monoclínica y las sustituciones iónicas observadas son bastante menores que en la alita trigonal. Esta alita monoclínica es comparable a la de un clínker comercial, siendo su reactividad con el agua proporcional a la temperatura de templado, dentro de amplios límites y que para temperaturas de temple elevadas (1.400-1.600" C), da resistencias mecánicas elevadas.

La fase ferrítica de los clinkeres templados al agua tiene una composición aproximada de

\section{DISCUSSION}

The experimental results we obtained do not seem to be in accordance with bibliographic data with respect to the influences of quenching in clinker phase crystallization and its mechanical resistance.

It must be taken into account that in our case the treatment temperatures were very high $\left(1.576^{\circ}\right.$ C) and the A.Q.C. and W.Q.C. was much rougher than commercial clinker treatment.

From microscopy it has been established that the alite in Portland cement clinker appears in the following forms: $M_{1}$ and $M_{3}$ (7) (8) (9). By $X$-Ray diffraction the two identified forms are: $R$ (trigonal) and $M_{1}$ (of the $M_{1 b}$ type) (10). The $M_{1 b}$ form had an X-Ray diffractogram very similar to $M_{3}(11)$.

We have identified, through the X-Ray diffraction patterns, a trigonal structured alite in the W.Q.C. wich is the highest temperature polymorphic form. The A.Q.C. had an alite of the monoclinic type, possibly a mix of the $M_{1}$ and $M_{3}$ forms.

A possible justification for the low mechanical strength obtained from the W.Q.C. could be the establishment of this trigonal alite which has its $\mathrm{Ca}$ and $\mathrm{Al}$ substituded by $\mathrm{Mg}$ and $\mathrm{Al}$ respectively (observed by dispersive X-Ray analysis). These substitution make room for the formation of relatively large sized crystals with very marked and straight profiles, therefore having less reactivity in the presence of water thereby justifying the low flexotraction and compression strength of the water quenched clinkers. On the other hand, it is known that the decrease of distance of the $\mathrm{Ca}-\mathrm{O}$ bond by metalic substitution diminishes reactivity.

The air quenched clinkers have a monoclinic alite and the ionic substitutions observed are quite a bit smaller than in the trigonal alite. This monoclinic alite is comparable to that of a commercial clinker in so far as its reactivity with the water is proportional to the quenching temperature, within wide limits, and with high treatment temperatures has high mechanical strength.

The ferritic phase of the W.Q.C. has an approximate composition of $C_{6} A F_{2}$ which 
$\mathrm{C}_{6} \mathrm{AF}_{2}$, es decir es rica en óxido de hierro y pobre en alúmina. La fase ferrítica de los clínkeres templados al aire tiene una composición comprendida entre $\mathrm{C}_{4} \mathrm{AF}-\mathrm{C}_{2} \mathrm{~A}_{6} \mathrm{~F}$, es decir, es mucho más rica en alúmina; estos últimos datos obtenidos por nosotros, concuerdan con las conclusiones de los autores T. Vázquez, M. T. Blanco-Varela y A. Palomo (12)

\section{CONCLUSIONES}

- En todos los clínkeres templados al agua desde $1.100^{\circ} \mathrm{C}$ hasta $2.576^{\circ} \mathrm{C}$ se obtiene alita de estructura trigonal. Si el templado se hace al aire desde las mismas temperaturas se obtiene alita de tipo monoclínico, posiblemente una mezcla de las formas $M_{1}+M_{3}$.

- La alita de estructura trigonal tiene $\mathrm{Mg}$ y $\mathrm{Al}$ en disolución sólida y es más difícilmente hidratable que la alita de estructura monoclínica que no contiene dichos compuestos.

- Las resistencias mecánicas a flexotracción y compresión de los clínkeres 1, 2 y 3 templados al agua son siempre inferiores que las de los templados al aire.

- Las resistencias mecánicas del clínker 1 templado al agua son independientes de la temperatura de templado, mientras que las resistencias mecánicas del clínker templado al aire son mayores para temperaturas crecientes de templado entre 1.100 y $1.576^{\circ} \mathrm{C}$. means it is rich in iron oxide and poor in alumina. The ferritic phase of the A.Q.C. has a composition between $\mathrm{C}_{4} A F-C_{2} A_{6} F$, that is to say, it is much more richer in alumina. This last data obtained by us agrees with the conclusions of authors T. Vázquez, M. T. Blanco-Varela and A. Palomo (12).

\section{CONCLUSION}

- In all the W.Q.C. from $1.100^{\circ} \mathrm{C}$ a trigonal structured alite was obtained. If the quenching was done in the air from the same temperatures monoclinic type alite, possibly a mixture of the $M_{1}+M_{3}$ forms, was obtained.

- The trigonal structured alite has $\mathrm{Mg}$ and $\mathrm{Al}$ in solid solution and hydrates with much more difficulty than the monoclinic structured alite which does not contain the mentioned clinkers.

- The mechanical resistances: flexotraction and compression of clinkers $n .^{\circ} 1, n .^{\circ} 2$ and n. ${ }^{\circ}$, W.Q.C. are always inferior to those of the A.Q.C.

- The mechanical resistances of W.Q.C. n.o 1 are independent of the treatment temperature while the mechanical resistances of the A.Q.C. are greater with higher treatment temperatures between $1.100^{\circ} \mathrm{C}$ and $1.576^{\circ} \mathrm{C}$.

\section{B I B L I O G R A F I A}

(1) W. H. DUDA: Manual Tecnológico del cemento. 265-281 (1977).

(2) F. SORIA: Estudio de Materiales, 127-132 (1976).

(3) S. SPRUNG: VII Congrès International de la Chimie des cements, 1-2, 1-17 (1980).

(4) K. MOHAN and F. P. GLASSER: Cem. and Concr. Res. 7 (1977).

(5) TAKASHIMA, S.: Semento Gijutzu Nempo XII, 12-13 (1958).

(6) I. MAKI: II Cemento 76167 (1979).

(7) V. V. timasheU, A. T. SUleimenOV, A. Yu. SYChKaREVA and A. I. TLeUBeRTENOVA: Cement. No. 5, 8 (1979).

(8) M. REGOURD and A. GUINIER: Principal paper presentado al 6Th. Int. Symp. Chem. cement, Moscow (1974).

(9) E. WOERMAN: W. Eysel and Th. Hahn, Zement-Kalk-Gips 22, 414.

(10) T. VAZQUEZ, M. T. BLANCO-VARELA and A. PALOMO: Proceeding N. 35 British Ceramic Society, edited by F. P. Glasser (1984) 